\title{
PENYEBAB TERJADINYASUBSTANDARD PRACTICE BERDASARKAN TEORI LOSS CAUSATION MODEL PADA PENGELAS DI PT BANGUN SARANA BAJA
}

\author{
CAUSE OF SUBSTANDARD PRACTICE BASED ON THEORY OF \\ LOSS CAUSATION MODEL ON WELDER AT PT. BANGUN SARANA BAJA
}

\author{
Dimas Trianggoro Wicaksono \\ Perhimpunan Sarjana Kesehatan Masyarakat Indonesia (PERSAKMI), Surabaya, Jawa Timur \\ E-mail: tw.samid@gmail.com
}

\begin{abstract}
Welder had important role for steel fabrication industry, otherwise the job of welder had a variously dangerous potential. The occurring of substandard practice could be prevent by identified the cause of substandard practice. The aim of this research was to study the cause of the occurring of substandard practice on welder at PT. Bangun Sarana Baja. This research was done by using cross sectional design and qualitative approach in order to describe the cause of the occurring of substandard practice on welder at PT. Bangun Sarana Baja Gresik. The respondent of this research was 20 peoples who was work as a welder at PT. Bangun Sarana Baja. The result of this research represent that $80 \%$ of welder at PT. Bangun Sarana Baja had performed standard practice. Management has given a lot of variously programs. Personal factor and job factor most of welder supported the occurring of standard practice. The conclusion of this research was most of welder at PT. Bangun Sarana Baja has performed standard practice. Substandard practice occurred because the lack of welder participation in training and the lack of experience before they worked at PT. Bangun Sarana Baja as the personal factor, the difficulty of PPE arrangement, the careless of used PPE, work not based on SOP as the job factor, and lack of control of management on compliance to make standard for each program.
\end{abstract}

Keywords: substandard practice, personal factor, job factor, lack of control of management

\begin{abstract}
ABSTRAK
Pengelas memiliki peran penting dalam industri fabrikasi baja, selain itu pengelas juga mempunyai potensi bahaya yang beragam. Terjadinya substandard practice dapat dicegah dengan mengidentifikasi penyebabnya. Tujuan penelitian ini adalah mempelajari penyebab terjadinya substandard practice pada pengelas di PT. Bangun Sarana Baja. Penelitian dilaksanakan menggunakan rancangan cross sectional dengan menggunakan pendekatan kualitatif agar dapat menggambarkan penyebab terjadinya substandard practice pada pengelas di PT. Bangun Sarana Baja Gresik. Responden dalam penelitian ini sebanyak 20 orang yang merupakan pengelas di PT. Bangun Sarana Baja. Hasil penelitian menunjukkan bahwa 80\% pengelas di PT. Bangun Sarana Baja telah melakukan standard practice. Manajemen telah memberikan banyak program yang beragam. Faktor personal dan faktor pekerjaan pada sebagian besar pengelas mendukung terciptanya standard practice. Dari penelitian ini dapat disimpulkan bahwa pengelas di PT. Bangun Sarana Baja sebagian besar telah melakukan standard practice. Substandard practice terjadi karena kurangnya partisipasi pengelas dalam pelatihan dan kurangnya pengalaman pada bidang pengelasan sebelum bekerja di PT. Bangun Sarana Baja sebagai faktor personal, penyediaan APD yang rumit dan lama, kelalaian dalam memakai APD, bekerja tidak sesuai dengan SOP sebagai faktor personal, dan kurangnya pengendalian dari perusahaan dalam pembuatan standar untuk setiap program.
\end{abstract}

Kata kunci: substandard practice, faktor personal, faktor pekerjaan, lack of control of management

\section{PENDAHULUAN}

Indonesia sebagai negara berkembang memiliki berbagai macam bidang usaha, salah satunya adalah perindustrian. Berbagai jenis industri ada di Indonesia mulai dari industri rumah tangga hingga industri besar yang di dalamnya juga terdapat tenaga kerja dengan jumlah sesuai dengan jenis industri tersebut. Industri baja tergolong sebagai industri vital karena menyediakan bahan yang dibutuhkan oleh industri lainnya seperti industri otomotif, infrastruktur dan konstruksi. Berbagai macam proses terdapat di industri baja, dari tahap peleburan biji baja, pencetakan, hingga menjadi bahan yang siap untuk dikirimkan ke industri lain. Proses peleburan dan pencetakan biasanya dilakukan oleh tenaga mesin otomatis dengan suhu tinggi, 
kemudian melalui proses pendinginan yang cepat dan memperkuat kualitas baja.

Kemajuan industri global mendorong tingginya produktivitas, oleh karena itu penerapan keselamatan dan kesehatan kerja (K3) sangat dibutuhkan untuk melindungi baik tenaga kerja maupun orang lain atas hak keselamatannya yang berada pada suatu industri serta sumber produksi suatu industri dapat terpelihara dan digunakan secara efisien (Suma'mur, 2009).

Industri baja di bidang konstruksi hanya melakukan pengolahan, perancangan, serta fabrikasi baja sehingga siap digunakan untuk mendirikan suatu konstruksi bangunan. Fabrikasi baja merupakan tahap dimana baja disusun dan disatukan sedemikian rupa sehingga memenuhi rancangan yang telah disusun. Penyatuan serta penyusunan baja dilakukan oleh tenaga manusia yang diantaranya terdapat proses penyusunan, penyatuan dengan pengelasan, dan pada tahap akhir adalah pengecatan baja. Setiap tahap dalam proses fabrikasi memiliki potensi bahaya yang berbeda terlebih lagi proses tersebut dilakukan oleh tenaga manusia sehingga dapat memicu terjadinya kecelakaan kerja. Suma'mur (2009) menyatakan bahwa penyebab dari kecelakaan kerja adalah manusia dan kondisi lingkungan.

Pengelasan merupakan suatu kegiatan penting pada proses fabrikasi baja untuk menyatukan dua buah baja sesuai dengan susunan dan rancangan yang telah ditetapkan. Pengelasan atau welding adalah penyambungan dua bahan atau lebih yang didasarkan pada prinsip-prinsip proses difusi, sehingga terjadi penyatuan bagian bahan yang disambung (Riswan, 2008). Las merupakan ikatan metalurgi pada sambungan logam atau logam paduan yang dihasilkan oleh pemanasan pada suhu tertentu atau temperatur yang sesuai dengan atau tanpa penggunaan tekanan, dan dengan atau tanpa pemakaian logam pengisi (Siswanto, 2009).

Penelitian Safrin (2007) menyebutkan bahwa kasus kecelakaan kerja yang terjadi pada bagian welder adalah luka bakar di bagian tangan dan muka pada saat melakukan pengelasan. Data kecelakaan kerja pada tahun 2005-2006 menunjukkan jumlah kecelakaan yang disebabkan oleh terkena serpihan las di wajah dan tangan menduduki peringkat ke 1 dari 16 jenis penyebab dalam 14 divisi di PT. PAL Indonesia. Para pekerja di perusahaan itu seharusnya telah mendapatkan langkah kerja serta cara pemakaian APD yang benar, namun dalam implementasinya masih saja terjadi kecelakaan pada bagian tubuh yang seharusnya terlindungi oleh APD.

Kecelakaan kerja mempunyai beberapa faktor penyebab diantaranya adalah kondisi tidak aman dan perilaku tidak aman atau yang sering dikenal dengan unsafe act dan unsafe condition. Sebuah penelitian mengatakan bahwa lebih dari $90 \%$ kecelakaan kerja disebabkan oleh unsafe act. Dalam penelitian DuPont tercatat bahwa $76 \%$ kecelakaan kerja disebabkan oleh unsafe act, 22\% karena kombinasi dari unsafe act dan unsafe condition, $4 \%$ disebabkan karena unsafe condition.

PT Bangun Sarana Baja merupakan industri yang bergerak di bidang fabrikasi baja dimana dalam pengerjaannya terdapat proses pengelasan baja. Pengelasan atau welding adalah penyambungan dua bahan atau lebih yang didasarkan pada prinsipprinsip proses difusi, sehingga terjadi penyatuan bagian bahan yang disambung (Riswan, 2008).

Seperti pada perusahaan besar yang lainnya, PT. Bangun Sarana Baja mempunyai target zero accident. Target tersebut menuntut perusahaan untuk menegakkan keselamatan dan kesehatan setiap tenaga kerja guna mencegah terjadinya kecelakaan. Menurut Shappell dan Wiegman (2000). Antara 70 dan 80 persen dari kecelakaan penerbangan dapat dikaitkan dengan kesalahan manusia (tindakan tidak aman). Beberapa penelitian terdahulu juga menyebutkan bahwa terjadinya kecelakaan lebih banyak didominasi oleh tindakan tidak aman dari pada kondisi tidak aman. Teori Loss Causation Model dari Bird dan Germain merupakan salah satu cara mengidentifikasi serta mengurangi terjadinya kerugian akibat kecelakaan kerja. Teori tersebut menyebutkan bahwa penyebab langsung dari terjadinya kecelakaan adalah praktek dan kondisi substandar dimana istilah tersebut digunakan sebagai pengganti istilah perilaku dan kondisi tidak aman.

PT. Bangun Sarana Baja sebagai industri fabrikasi baja dengan proses pengelasan yang menggunakan tenaga manusia berpotensi terjadi substandard practice terutama dalam hal pemakaian APD. Penyebab terjadinya substandard practice dapat diidentifikasi melalui faktor personal dan faktor pekerjaan sebagai komponen dari basic cause serta melalui lack of control yang merupakan upaya pengendalian dari perusahaan. Tujuan penelitian ini adalah untuk mempelajari penyebab terjadinya substandard practice pada pengelas di PT. Bangun Sarana Baja. 


\section{METODE}

Penelitian yang dilakukan termasuk penelitian observasional karena peneliti melakukan observasi pada sampel penelitian dan tidak memberikan perlakuan pada subjek penelitian. Penelitian ini juga tergolong dalam penelitian deskriptif karena hanya melihat dan menggambarkan penyebab dari terjadinya substandard practice pada pengelas di PT Bangun Sarana Baja berdasarkan teori Loss Causation Model dari Bird dan Germain (1992). Menurut dimensi waktu, penelitian ini merupakan cross sectional study, karena data yang dikumpulkan pada satu kurun waktu saja, yaitu pada saat melaksanakan praktek penelitian di lapangan.

Penelitian dilaksanakan di PT Bangun Sarana Baja yang terletak di Jl. Mayjend Sungkono XII/8 Gresik, Jawa Timur. Penelitian dilaksanakan pada Desember-Januari Tahun 2013.

Populasi penelitian ini adalah seluruh pekerja di bagian pengelasan pada PT Bangun Sarana Baja yang berjumlah 20 orang. Sampel penelitian ini diambil dari keseluruhan total populasi yakni 20 orang. Dalam penelitian ini juga melibatkan perwakilan pihak manajemen yang akan membantu melengkapi daftar periksa.

Teknik pengumpulan data primer diperoleh dari daftar periksa mengenai program perusahaan, pengisian kuesioner oleh pengelas dan juga hasil observasi peneliti selama penelitian berlangsung. Sedangkan data sekunder merupakan gambaran umum perusahaan, SOP program, jadwal kegiatan program, dan studi kepustakaan mengenai kebijakan perusahaan tentang $\mathrm{K} 3$, peraturan perusahaan tentang $\mathrm{K} 3$, serta data penunjang yang lain.

Teknik analisis data dilakukan dengan melakukan koding terlebih dahulu untuk mempermudah analisa. Hasil penelitian akan dideskripsikan dengan menggunakan tabel distribusi frekuensi dan analisis persentase. Santoso dan Tjiptono (2004), Metode tabulasi silang digunakan untuk melihat hubungan antara dua variabel dalam satu tabel. Tabulasi silang merupakan cara termudah melihat asosiasi dalam sejumlah data dengan perhitungan persentase. Tabulasi silang merupakan salah satu alat yang paling berguna untuk mempelajari hubungan di antara variabel karena hasilnya mudah dikomunikasikan.

\section{HASIL}

\section{Program yang Dilakukan oleh Manajemen}

Program yang dilakukan manajemen diidentifikasi berdasarkan daftar periksa dari buku Practical Loss Control Leadership dari Bird dan Germain (1992). Daftar periksa tersebut diteliti melalui wawancara kepada pihak manajemen mengenai program $\mathrm{K} 3$ apa saja yang dijalankan oleh manajemen beserta penjelasan program yang kemudian akan disesuaikan dengan daftar periksa. Daftar periksa disajikan dalam bentuk persentase program yang telah dipenuhi dan yang belum dipenuhi. Persentase didapatkan dari penghitungan program yang dilaksanakan berdasarkan total daftar periksa. Berikut merupakan tabel kesesuaian program pengendalian dengan daftar periksa berdasarkan Bird dan Germain (1992) yang dilakukan PT. Bangun Sarana Baja.

Hasil penelitian menyatakan bahwa PT. Bangun Sarana Baja telah melaksanakan (85\%) program dari daftar periksa menurut Bird dan Germain (1992). Program yang tidak dijalankan oleh PT. Bangun Sarana Baja adalah program mengenai pengamatan tugas/pekerjaan terencana, pengulasan peraturan tahunan untuk pekerja, menjadi tim proyek pengendalian kerugian, menyelenggarakan pemeliharaan APD, menggunakan teknik pelatihan dan pengajaran yang efektif.

Selain itu manajemen juga mengaku bahwa PT. Bangun Sarana Baja mempunyai 14 buah program K3 yang telah berjalan antara lain safety talk, HSE meeting bulanan, HSE induction, HSE sharing, HSE internal skill training, $\mathrm{K} 3$ workshop, inspeksi APAR, inspeksi APD, mading K3, inspeksi ID card dan safety shoes, investigasi dan pelaporan kecelakaan, laporan harian, inspeksi crane, dan inspeksi forklift.

\section{Standar Program yang Dijalankan oleh PT. Bangun Sarana Baja}

Daftar standar program yang dibuat oleh Bird and Germain (1992) menjelaskan mengenai komponen program yang wajib dilaksanakan oleh perusahaan yang dapat dilihat dalam SOP. Daftar periksa berisi 10 contoh standar program sederhana dari Bird dan Germain (1992). Hasil penelitian menyatakan bahwa standar program 
yang dilakukan PT. Bangun Sarana Baja sudah memenuhi $(90 \%)$ daftar periksa. PT. Bangun Sarana Baja hanya mempunyai 4 buah SOP untuk program P3K, evakuasi, investigasi kecelakaan, dan inspeksi mobil forklift oleh karena itu diambil sumber lain yakni dari form yang dibuat oleh PT. Bangun Sarana Baja untuk mendukung program yang telah dilaksanakan.

\section{Kesesuaian antara Pelaksanaan dengan Program PT. Bangun Sarana Baja}

Kesesuaian standar program didapatkan melalui wawancara pada pihak manajemen khususnya departemen HSE PT. Bangun Sarana Baja. Wawancara dilakukan dengan tujuan untuk mengetahui program yang dijalankan oleh PT. Bangun Sarana Baja, penjelasan program, pelaksana program, partisipan serta jadwal program tersebut. PT. Bangun Sarana Baja mempunyai jadwal tahunan program yang harus dilaksanakan. Seluruh program yang telah direncanakan oleh PT. Bangun Sarana Baja telah terlaksana sesuai dengan jadwal dan tanggung jawab masing-masing anggota departemen HSE.

\section{Identifikasi Faktor Personal Pengelas di PT. Bangun Sarana Baja}

Pengetahuan menjadi salah satu komponen dalam penegakan keselamatan kerja. Dalam aspek pengetahuan, penilaian dilakukan khususnya pada pengetahuan mengenai kesehatan dan keselamatan kerja yang telah didapatkan oleh pengelas mulai dari awal bekerja sampai dengan penelitian ini dimulai. Kuesioner mengenai pengetahuan terdiri dari 3 pertanyaan mengenai pengertian $\mathrm{K} 3$, kecelakaan kerja, dan perilaku tidak aman dalam bekerja dan 3 pertanyaan mengenai keikutsertaan pengelas dalam program orientasi perusahaan, pelatihan $\mathrm{K} 3$ dan pengalaman kerja sebelumnya.

Tabel hasil kuesioner pengetahuan pada pengelas di PT. Bangun Sarana Baja menjelaskan tentang skor yang didapatkan oleh pengelas dari tiap pertanyaan kuesioner. Tabel hasil kuesioner pengetahuan pada pengelas PT Bangun Sarana Baja mengidentifikasikan bahwa (95\%) pengelas mengetahui arti $\mathrm{K} 3$ dalam perusahaan, demikian pula $(65 \%)$ mengetahui arti kecelakaan kerja dan $60 \%$ mengetahui arti perilaku tidak aman sehingga dapat diartikan bahwa sebagian besar pengelas telah mengerti arti K3, kecelakaan kerja dan perilaku tidak aman.
Tabel hasil kuesioner pengetahuan pada pengelas PT Bangun Sarana Baja juga mengidentifikasikan bahwa sebanyak (90\%) pengelas menghadiri dan menerima seluruh penjelasan mengenai lingkungan kerja, peraturan yang terkait dengan pekerjaan namun hanya $(25 \%)$ pengelas yang berpartisipasi dalam pelatihan K3 yang diadakan oleh perusahaan. Berdasarkan hasil tersebut dapat digambarkan bahwa sebagian besar pengelas tidak pernah mengikuti pelatihan namun hampir seluruh pengelas mengikuti program orientasi yang diadakan oleh perusahaan.

Sebanyak (70\%) pengelas juga mengaku tidak pernah bekerja pada bidang yang sama sebelumnya juga dapat diartikan bahwa pekerja tidak mempunyai pengetahuan dan pengalaman mengenai bidang pengelasan sebelum bekerja sebagai pengelas di PT. Bangun Sarana Baja.

Pengetahuan dikategorikan menjadi 3 yakni kategori baik, sedang, dan buruk. Kategori didapatkan dengan menjumlah skor dari kuesioner pengetahuan kemudian disesuaikan dengan range dari setiap kategori.

Hasil penelitian menyatakan bahwa sebanyak (20\%) pengelas mempunyai pengetahuan yang baik, (75\%) mempunyai pengetahuan sedang dan $(5 \%)$ mempunyai pengetahuan yang buruk. Hal ini dapat terjadi akibat kurangnya partisipasi dalam pelatihan dan kurangnya pengalaman dalam bidang kerja pengelas. Kategori pengetahuan pengelas sekaligus menggambarkan kategori faktor personal yang dimiliki oleh pengelas.

\section{Identifikasi Faktor Pekerjaan Pengelas di PT. Bangun Sarana Baja}

Faktor lain yang berkaitan dengan faktor personal dalam membentuk penyebab dasar ialah faktor pekerjaan. Faktor pekerjaan mempunyai berbagai macam aspek namun dalam penelitian ini hanya diambil dari 2 aspek yakni peralatan dan perlengkapan serta aspek kesalahan dan penyalahgunaan. Faktor pekerjaan dikategorikan menjadi 3 yakni kategori baik, sedang, dan buruk. Kategori didapatkan dengan menjumlah skor dari kuesioner peralatan dan perlengkapan serta aspek kesalahan dan penyalahgunaan kemudian disesuaikan dengan range dari setiap kategori.

Distribusi kategori faktor pekerjaan pengelas di PT. Bangun Sarana Baja. Hasil penelitian menyatakan bahwa (65\%) pengelas yang menganggap bahwa faktor pekerjaan berada pada kategori baik. Hal ini dapat diartikan bahwa faktor pekerjaan sepenuhnya telah mendukung melaksanakan pekerjaan. 


\section{Identifikasi Pemakaian APD pada Pengelas di PT. Bangun Sarana Baja}

Kesalahan dalam pemakaian APD merupakan salah satu contoh dari immediate cause yang dapat menyebabkan kecelakaan kerja. Observasi dibuat berdasarkan pedoman dari Siswanto (1994) mengenai alat pelindung diri pada pengelas dan disesuaikan dengan APD yang disediakan oleh perusahaan yakni apron, heat gloves, dan safety shoes. Perilaku dikategorikan menjadi 2 yaitu standard dan substandard. Distribusi kategori perilaku pemakaian APD pada pengelas di PT. Bangun Sarana Baja. Hasil penelitian menyatakan bahwa hampir seluruh pengelas yakni $(60 \%)$ telah melakukan tindakan standar dengan memakai APD yang benar, sesuai dan dalam kondisi yang baik dan (40\%) melakukan tindakan substandard dengan memakai APD yang tidak sesuai dan atau dalam kondisi yang tidak layak. Penilaian observasi diambil berdasarkan pemakaian serta kondisi 4 buah APD yakni face shield, heat gloves, apron dan safety shoes.

\section{Penyebab Terjadinya Substandard Practice Berdasarkan Teori Loss Causatio Model pada Pengelas di PT. Bangun Sarana Baja}

Telah diketahui sebelumnya bahwa permasalahan pada pemakaian APD terletak pada kondisi safety shoes yang tidak layak dan pemakaian face shield yang tidak benar kemudian permasalahan pada faktor personal terletak pada kurangnya partisipasi dalam program pelatihan dan pengalaman pengelas sebelum bekerja di PT. Bangun Sarana Baja, selain itu permasalahan faktor pekerjaan terletak pada proses penyediaan APD yang lama, bekerja tidak sesuai SOP, dan kelalaian dalam memakai APD.

Penyebab terjadinya substandard practice diidentifikasi dengan menggunakan tabulasi silang antara faktor personal dan faktor pekerjaan dengan perilaku pemakaian APD. Selain itu tabulasi silang juga dilakukan pada setiap permasalahan dalam faktor personal, faktor pekerjaan dan pemakaian APD dengan tujuan untuk mengetahui distribusi permasalahan dalam faktor personal dan faktor pekerjaan berdasarkan permasalahan dalam pemakaian APD pada pengelas di PT. Bangun Sarana Baja.

Berdasarkan Gambar 1 diketahui bahwa pengelas yang berada dalam kategori substandard sebanyak $(46,7 \%)$ berasal dari pengelas dengan

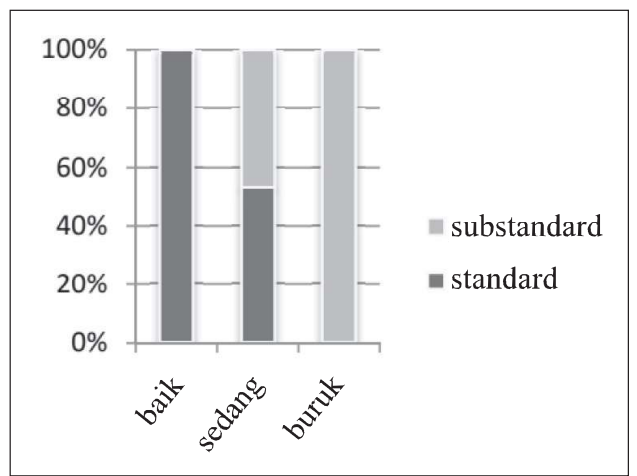

Gambar 1. Diagram Distribusi Kategori Pengetahuan Berdasarkan Perilaku Pemakaian APD pada Pengelas di PT. Bangun Sarana Baja.

faktor personal yang berada pada kategori sedang dan $(100 \%)$ berasal dari pengelas dengan pengetahuan yang berada pada kategori buruk. Hal tersebut mengidentifikasikan bahwa substandard practice lebih banyak terjadi pada pengelas dengan pengetahuan yang berada pada kategori sedang. Hasil tabulasi silang partisipasi pengelas dalam pelatihan berdasarkan pemakaian safety shoes mengidentifikasikan bahwa sebanyak $(65 \%)$ pengelas tidak mengikuti pelatihan dan menggunakan safety shoes dalam kondisi yang tidak baik. Hasil tabulasi silang partisipasi pengelas dalam pelatihan berdasarkan pemakaian face shield mengidentifikasikan bahwa sebanyak (40\%) pengelas tidak mengikuti pelatihan dan menggunakan face shield dengan tidak benar.

Berdasarkan Gambar 2 diketahui bahwa pengelas yang berada dalam kategori substandard

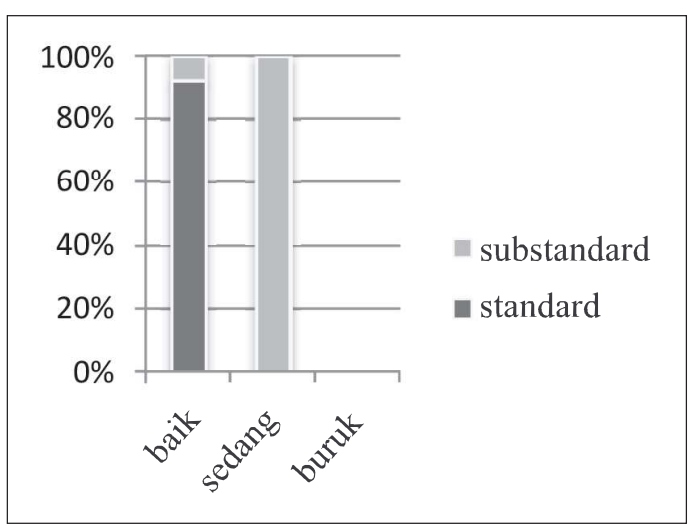

Gambar 2. Diagram Distribusi Kategori Faktor Pekerjaan Berdasarkan Perilaku Pemakaian APD pada Pengelas di PT. Bangun Sarana Baja. 
sebanyak (100\%) berasal dari pengelas dengan faktor pekerjaan yang berada pada kategori sedang. Mengidentifikasikan bahwa practice terjadi pada pengelas Hal tersebut substandard dengan faktor.

Faktor personal dapat dilihat secara rinci melalui 2 komponen yakni komponen peralatan dan perlengkapan serta komponen pengawasan perhatian pada penyalahgunaan dan kesalahan pada pengelas di PT. Bangun Sarana Baja.

Berdasarkan Gambar 3 diketahui bahwa pengelas yang berada dalam kategori substandard sebanyak $(88,89 \%)$ berasal dari pengelas dengan peralatan dan perlengkapan yang berada pada kategori sedang. Hal tersebut mengidentifikasikan bahwa substandard practice terjadi pada pengelas dengan peralatan dan perlengkapan dalam kategori sedang.

Hasil tabulasi silang mengenai proses penyediaan APD berdasarkan pemakaian safety shoes mengidentifikasikan bahwa (50\%) pengelas beranggapan bahwa proses penyediaan APD yang lama dan rumit menggunakan safety shoes dengan kondisi tidak layak. Hasil tabulasi silang mengenai proses berdasarkan face shield mengidentifikasikan hanya $(30 \%)$ pengelas beranggapan bahwa proses penyediaan APD yang lama dan rumit, menggunakan face shield dengan tidak benar.

Berdasarkan Gambar 4 diketahui bahwa pengelas yang berada dalam kategori substandard sebanyak $(60 \%)$ berasal dari pengelas dengan pengawasan penyalahgunaan dan kesalahan yang berada pada kategori sedang dan $(100 \%)$ berasal dari pengelas dengan pengawasan perhatian pada

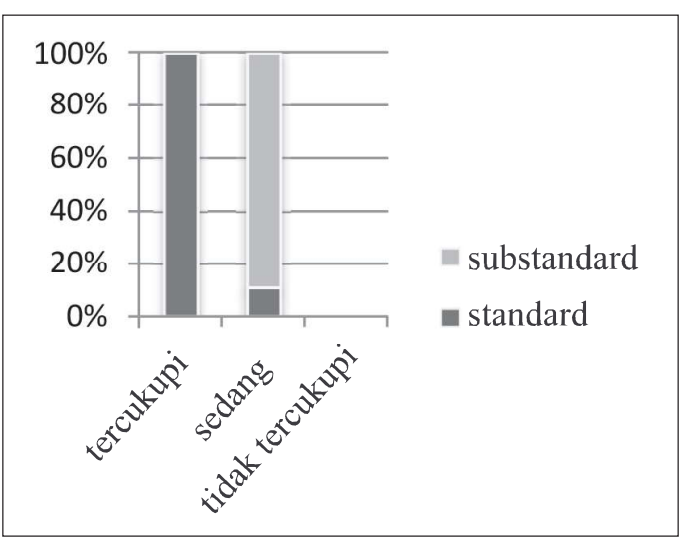

Gambar 3. Distribusi Kategori Perlengkapan Peralatan dan Berdasarkan Perilaku Pemakaian APD pada Pengelas di PT. Baja Bangun Sarana

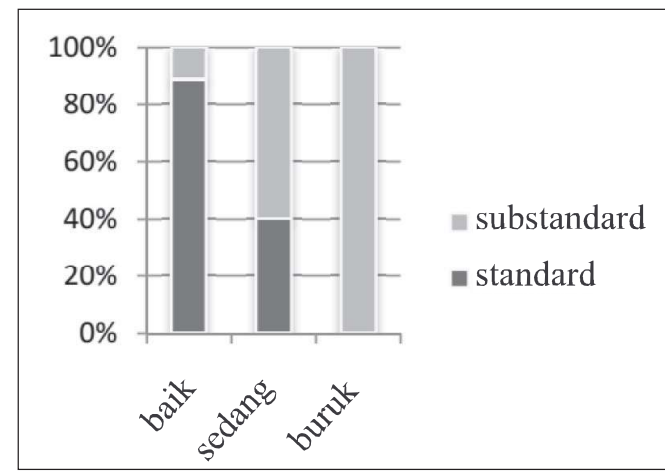

Gambar 4. Distribusi Kategori Perhatian pada Penyalahgunaan dan Kesalahan Berdasarkan Perilaku Pemakaian APD pada Pengelas di PT. Bangun Sarana Baja

penyalahgunaan dan kesalahan yang berada pada kategori buruk. Hal tersebut mengidentifikasikan bahwa substandard practice terjadi pada pengelas dengan peralatan dan perlengkapan dalam buruk.

Hasil tabulasi kesesuaian terhadap SOP berdasarkan pemakaian safety shoes mengidentifikasikan bahwa (45\%) pengelas bekerja tidak sesuai dengan SOP dan menggunakan safety shoes dengan kondisi tidak layak. Hasil tabulasi silang mengenai kesesuaian terhadap SOP berdasarkan pemakaian face shield mengidentifikasikan hanya (35\%) pengelas bekerja tidak sesuai dengan SOP dan menggunakan face shield dengan tidak benar.

\section{PEMBAHASAN}

\section{Pengendalian yang Dilakukan Manajemen}

Domino Bird dan Germain (1992) menggambarkan proses terjadinya kecelakaan kerja yang berujung pada kerugian bagi perusahaan. Domino tersebut diawali dengan lemahnya pengendalian dari manajemen. Pengendalian manajemen menyangkut 3 hal yang ada di dalamnya yakni program, standar program, dan pemenuhan terhadap standar program apabila ketiga hal tersebut telah terpenuhi maka perusahaan akan terhindar dari kerugian akibat kecelakaan kerja (Bird dan Germain, 1992).

Hasil penelitian menunjukkan bahwa PT. Bangun Sarana Baja telah membuat serta melaksanakan program yang jumlahnya banyak dan bervariasi. Hal ini sesuai dengan pernyataan Bird dan Germain (1992) bahwa program pengendalian akan 
menjadi tidak memadai apabila jumlah dan variasi program terlalu sedikit. Sementara itu, didapati permasalahan mengenai kurang lengkapnya standar program kesehatan dan keselamatan kerja, dari 14 program $\mathrm{K} 3$, hanya terdapat 4 standar program sehingga menjadi tidak sesuai dengan ungkapan Bird dan Germain (1992) mengenai standar program yang disusun harus sangat efektif, jelas dan kuat. Hal ini juga terkait dengan pemenuhan standar program sebab PT. Bangun Sarana Baja tidak mempunyai standar tentang program $\mathrm{K} 3$ yang telah direncanakan. Penyusunan standar program merupakan pemenuhan dari salah satu fungsi manajemen yakni planning. Standar program yang dimaksud adalah standar operasional prosedur yang di dalamnya terdapat penjelasan secara rinci mengenai program K3 yang akan dilaksanakan. SOP merupakan suatu bentuk peraturan, menurut Geller (2001), peraturan merupakan dokumen tertulis yang mendokumentasikan standar, norma, dan kebijakan untuk perilaku yang diharapkan.

Ungkapan Geller tersebut dapat dimaknai bahwa SOP juga berisi perilaku yang harus dilakukan untuk menjalankan suatu pekerjaan atau program. Selain itu dapat juga dimaknai bahwa SOP dapat mempermudah dalam memberikan penilaian terhadap program ataupun terhadap kinerja.

Bird and Germain (1992) mengungkapkan bahwa standar dibuat untuk mempermudah pengukuran terhadap program yang telah berjalan. Standar program merupakan sebuah tolak ukur keberhasilan sebuah program. Hal ini terkait dengan fungsi manajemen yang terakhir yakni controlling, manajemen mengukur berjalannya suatu program atau kinerja melalui standar yang telah dibuat.

Berdasarkan uraian di atas dapat ditarik kesimpulan bahwa program pengendalian PT. Bangun Sarana Baja masih kurang baik dan hendaknya dapat menyusun standar dari setiap program $\mathrm{K} 3$ yang dijalankan agar program tersebut dapat mencapai tujuan yang diharapkan.

\section{Faktor Personal}

Basic cause adalah penyebab nyata dari suatu gejala, alasan substandard act dan substandard conditions muncul (Bird dan Germain, 1992). Basic cause atau penyebab dasar mempunyai dua komponen yakni faktor personal dan faktor pekerjaan. Faktor personal dijabarkan melalui segala bentuk kendala yang berasal dari dalam diri seseorang seperti kemampuan fisiologi, psikologi, tekanan fisik, tekanan mental, pengetahuan, keahlian dan motivasi (Bird dan Germain, 1992). Penelitian ini hanya menguji komponen pengetahuan pengelas mengenai $\mathrm{K} 3$ dan berdasarkan hasil penelitian didapatkan bahwa pengetahuan pengelas mengenai $\mathrm{K} 3$ berada dalam kategori sedang yang disebabkan oleh kurangnya partisipasi pengelas dalam pelatihan dan pengalaman dalam bidang pengelasan sebelum bekerja di PT. Bangun Sarana Baja.

Salah satu faktor yang menjadi penyebab pengetahuan pengelas mengenai K3 adalah partisipasi pengelas dalam pelatihan. Partisipasi dapat diartikan sebagai keikutsertaan dalam suatu kegiatan. Pelatihan merupakan suatu proses sesorang mendapatkan pengetahuan atau informasi atau maklumat mengenai sesuatu yang baru. Pelatihan merupakan sebuah media pengelas mendapatkan pengetahuan dengan jelas melalui panca indera terutama penglihatan dan pendengaran. Hal ini sejalan dengan pernyataan Notoadmodjo (2007) bahwa sebagian besar pengetahuan diperoleh melalui mata dan telinga.

Pelatihan erat hubungannya dengan pendidikan, mendidik juga melatih untuk mengembangkan keterampilan kerja para karyawan. Pendidikan dan pelatihan ini merupakan suatu bentuk investasi dan setiap instansi yang ingin berkembang maka harus memberikan perhatian yang besar terutama pada pendidikan dan pelatihan bagi karyawannya (Notoadmodjo, 2003). PT. Bangun Sarana Baja sebagai perusahaan yang ingin terus berkembang hendaknya dapat mengimbau pengelas untuk lebih berpartisipasi dalam program pelatihan yang diadakan oleh perusahaan.

Hasil penelitian juga mengungkapkan faktor lain yang menjadi penyebab kurangnya pengetahuan adalah karena sebagian besar pengelas tidak mempunyai pengalaman dalam bidang pengelasan sebelum bekerja di PT. Bangun Sarana Baja sehingga dapat diartikan bahwa pengelas tidak memiliki latar belakang yang mendukung dalam bidang pekerjaannya sesuai dengan ungkapan Handoko (2001) latar belakang pribadi merupakan faktor yang memengaruhi pengalaman, latar belakang tersebut mencakup pendidikan, kursus, latihan, dan bekerja.

Pengalaman juga membantu pengelas untuk mempermudah pekerjaan, sebagaimana diungkapkan oleh John (2007) bahwa pengalaman dapat memunculkan potensi penuh seiring berjalannya waktu. Ungkapan tersebut juga didukung oleh Mustaqim (2004) bahwa dalam law of exercise hubungan antara stimulus dan respons akan bertambah kuat atau erat bila sering digunakan. 
Selain itu, Foster (2001) juga mengungkapkan bahwa salah satu ciri seseorang yang berpengalaman adalah mampu menguasai pekerjaan maupun peralatan yang digunakannya. Uraian tersebut mengungkapkan bahwa dengan adanya pengalaman maka seseorang akan dapat bekerja dengan baik tanpa ada kekurangan dan tidak akan membahayakan dirinya maupun pihak yang ada di sekitarnya.

Berdasarkan uraian di atas maka dapat ditarik kesimpulan bahwa pengetahuan sebagai faktor personal diperoleh melalui berbagai cara yakni pelatihan dan pengalaman. Pelatihan sebagai pengembang keterampilan kerja dan pengalaman sebagai proses belajar untuk bekerja dengan baik dan tidak menimbulkan bahaya bagi diri sendiri maupun lingkungan sekitar.

\section{Faktor Pekerjaan}

Bird dan Germain (1992) dalam bukunya Practical Loss Control Leadership menyatakan bahwa faktor pekerjaan merupakan faktor yang berasal dari luar yang dapat menjelaskan penyebab terjadinya substandard practice dan substandard condition. Faktor pekerjaan dijabarkan melalui komponen yang berasal dari sisi pekerjaan seperti kepemimpinan dan atau pengawasan, teknisi, pengadaan barang, perawatan, peralatan dan perlengkapan, standar kerja, pemakaian dan kerusakan, kesalahan atau penyalahgunaan. Hasil penelitian mengungkapkan bahwa faktor pekerjaan pengelas di PT. Bangun Sarana Baja masuk dalam kategori sedang. Penelitian mengenai faktor pekerjaan mencakup komponen peralatan dan perlengkapan serta kesalahan dan penyalahgunaan yang dilakukan oleh pengelas.

Permasalahan yang ditemui dalam komponen peralatan dan perlengkapan adalah penyediaan APD melalui proses yang rumit dan lama sedangkan dalam komponen perhatian pada kesalahan atau penyalahgunaan ditemukan bahwa pengelas masih sering melalaikan kewajiban untuk memakai APD di area kerja.

Berdasarkan hasil penelitian, pengelas mengungkapkan bahwa proses penyediaan APD masih rumit dan melalui proses yang panjang. Hal tersebut tidak sejalan dengan Dalam UU No. 1 Tahun 1970 tentang Keselamatan Kerja pasal 14 butir c menyatakan bahwa pengurus (pengusaha) diwajibkan untuk mengadakan secara cuma-cuma, semua alat perlindungan diri yang diwajibkan pada tenaga kerja yang berada di bawah pimpinannya dan menyediakan bagi setiap orang lain yang memasuki tempat kerja tersebut, disertai dengan petunjukpetunjuk yang diperlukan menurut petunjuk pegawai pengawas atau ahli keselamatan kerja, sehingga seharusnya tidak ada alasan bagi perusahaan untuk menunda atau mempersulit penyediaan APD bagi pekerjanya.

APD termasuk dalam fasilitas penunjang terciptanya keselamatan kerja (Suma'mur, 1996). Pernyataan tersebut juga didukung oleh Sahab (1997) yang menyatakan bahwa fasilitas merupakan salah satu hal penting untuk mendukung terciptanya keselamatan di tempat kerja. Berdasarkan pentingnya APD dalam uraian tersebut maka diharapkan perusahaan mampu untuk melakukan evaluasi mengenai manajemen APD yang sudah berjalan di perusahaan.

Selain proses penyediaan APD, pekerja juga mengaku bahwa sesekali mereka lupa memakai APD saat bekerja, hal ini bertentangan dengan Peraturan Menteri Tenaga Kerja dan Transmigrasi Republik Indonesia No. PER. 08/MEN/VII/2010 tentang Alat Pelindung Diri pada pasal 6 yang menyebutkan bahwa setiap pekerja ataupun orang lain yang memasuki area kerja wajib memakai APD sesuai dengan potensi bahaya dan risiko yang ada di tempat kerja.

Kelalaian seperti ini merupakan salah satu bentuk kesalahan manusia yang dapat mengakibatkan timbulnya kecelakaan kerja (Reason, 2008).

Uraian tersebut menunjukkan kelalaian pengelas dalam menggunakan APD. Kelalaian tersebut merupakan suatu bentuk kurangnya perhatian pengelas mengenai pentingnya APD dalam menciptakan keselamatan kerja yang menyebabkan kelalaian dalam memakai APD walaupun pihak perusahaan telah mengumumkan mengenai kewajiban pemakaian APD, maka diharapkan perusahaan dapat meningkatkan kesadaran pekerjanya dengan mengadakan pelatihan mengenai penggunaan APD yang mencakup fungsi dan tata laksananya.

Pengelas di PT. Bangun Sarana Baja mengaku bahwa mereka sesekali bekerja tidak sesuai dengan prosedur tetap atau SOP. SOP merupakan suatu sarana yang dapat membantu memudahkan pekerjaan. SOP merupakan suatu bentuk peraturan yang harus dipatuhi oleh setiap pekerja seperti yang diungkapkan oleh Geller (2001) bahwa peraturan merupakan dokumen tertulis yang berisi tentang standar, norma, dan kebijakan untuk perilaku yang diharapkan. Pernyataan Geller tersebut dapat disimpulkan bahwa apabila pengelas tidak bekerja 
sesuai dengan SOP yang telah ditetapkan maka hal tersebut merupakan suatu bentuk pelanggaran, sejalan dengan pernyataan dari Reason (2008) bahwa kesalahan dalam mematuhi SOP merupakan kesalahan dan suatu pelanggaran.

Pelanggaran terhadap SOP merupakan salah satu bentuk substandard practice seperti yang disebutkan oleh Bird dan Germain (1992) bahwa substandard practice meliputi pengoperasian atau bekerja dengan kecepatan yang tidak aman, menggunakan peralatan yang tidak aman, memuat, menempatkan, mencampurkan menggabungkan dengan tidak aman, dan segala bentuk gangguan dan penyalahgunaan yang dilakukan oleh pekerja. Substandard practice merupakan komponen penyebab langsung terjadinya kecelakaan kerja yang seharusnya dihindari.

\section{Perilaku Pemakaian APD}

Pemakaian APD dengan benar merupakan salah satu tindakan aman atau dapat dikatakan standar practice. Bird dan Germain (1992) mengatakan bahwa dalam substandard practice terdapat komponen kegagalan dalam menggunakan APD dengan tepat, sehingga dalam penelitian ini dilakukan penelitian terhadap pemakaian APD pada pengelas di PT. Bangun Sarana Baja. Penilaian perilaku pemakaian APD dilihat dari sisi ketepatan penggunaan dan kondisi APD yang digunakan.

Berdasarkan hasil penelitian, perilaku pemakaian APD sebagian besar pengelas masuk dalam kategori standar practice, hal ini diartikan bahwa pengelas telah memakai APD yang tepat, sesuai dengan risiko dan bahaya yang ditimbulkan. Hal tersebut sesuai dengan ketentuan Permenakertrans No. PER.08/ MEN/VII/2010 tentang Alat Pelindung Diri pasal 6 yang menyatakan bahwa seluruh pekerja dan orang lain yang berada di area kerja diwajibkan untuk memakai alat pelindung diri yang sesuai dengan potensi bahaya dan risiko.

Hasil pengamatan secara rinci menunjukkan bahwa sebagian besar safety shoes yang digunakan oleh pengelas dalam kondisi yang tidak layak dan masih terdapat pengelas yang menggunakan face shield dengan tidak benar.

Kondisi safety shoes yang tidak layak tercatat karena sebagian besar pengelas menggunakan safety shoes dengan keadaan sol sepatu hampir terlepas. APD merupakan alat yang berfungsi untuk melindungi diri dari segala bentuk bahaya dan risiko yang ada di tempat kerja. APD seperti halnya peralatan yang lain, juga memerlukan perawatan yang khusus dan yang disarankan oleh vendor atau produsen APD.

Kondisi APD yang demikian hendaknya ditindaklanjuti oleh perusahaan seperti yang telah ada dalam ketetapan Permenakertrans No. PER.08/MEN/VII/2010 tentang Alat Pelindung Diri pasal 8 ayat 1 disampaikan bahwa APD yang rusak, retak atau tidak dapat berfungsi dengan baik harus dibuang dan atau dimusnahkan, ketetapan ini terkait dengan kegiatan inspeksi APD yang wajib dilakukan oleh perusahaan dan telah tertulis pada pasal 7 mengenai manajemen APD di tempat kerja. Dalam pasal tersebut diungkapkan secara rinci mengenai program atau kegiatan yang wajib dilakukan oleh perusahaan dalam mengelola APD di tempat kerja seperti identifikasi kebutuhan APD, penyediaan APD, pelatihan, penggunaan, perawatan dan penyimpanan, penatalaksanaan pembuangan atau pemusnahan, pembinaan, inspeksi, evaluasi, dan pelaporan.

PT. Bangun Sarana Baja telah menjalankan program inspeksi APD pada pekerja namun inspeksi hanya sebatas untuk mengetahui apakah pekerja memakai APD atau tidak, tanpa melihat kelayakan dari APD yang dipakai. APD yang tidak layak atau rusak sudah tidak mampu memenuhi fungsinya sebagai pelindung bagian tubuh dari bahaya dan risiko yang ada di area kerja dan bahkan dapat memungkinkan timbulnya risiko yang lain.

Substandard practice lain yang dilakukan oleh pengelas adalah kesalahan dalam pemakaian face shield. Pemakaian face shield yang tidak benar adalah ketika pengelas menggunakan face shield yang tidak menutup wajah. Face shield merupakan APD yang dirancang untuk melindungi wajah dari percikan material dan melindungi mata dari sinar non-ionisasi (Siswanto, 1994). Selain itu Siswanto (1994) juga mengungkapkan bahwa perlunya pelindung kepala bagi pengelas untuk melindungi rambut dari percikan logam dan bunga api yang panas serta kepala dari kejatuhan benda-benda, namun dari pihak perusahaan hanya menyediakan face shield sebagai pelindung bagian kepala untuk pengelas.

\section{Penyebab Substandard Practice Berdasarkan Loss Causation Model}

Substandard practice merupakan istilah yang digunakan untuk menggantikan unsafe act dengan tujuan bahwa setiap praktek akan dihubungkan dengan standar sebagai dasar untuk pengukuran, evaluasi dan koreksi (Bird dan Germain, 1992). 
Substandard practice mempunyai berbagai macam bentuk salah satunya adalah kegagalan untuk memakai alat pelindung diri. Seperti yang telah teridentifikasi bahwa hasil penelitian menyatakan bahwa sebagian besar pengelas berada dalam kategori standard practice yang berarti pengelas telah memakai APD dengan tepat. Pengelas yang tidak masuk dalam kategori standar disebabkan karena kondisi APD yang tidak baik dan kesalahan dalam pemakaian APD.

Substandard practice merupakan penyebab langsung terjadinya kecelakaan atau insiden. Kecelakaan atau insiden diartikan sebagai kontak dengan barang, substansi, ataupun manusia hingga akhirnya akan dapat memungkinkan terjadi kerugian yang menimpa manusia, peralatan, bahan, dan lingkungan (Bird dan Germain, 1992). Oleh sebab itu diperlukan adanya upaya pencegahan yang wajib dilakukan oleh manajemen. Langkah awal yang sangat penting dalam upaya pencegahan adalah mengetahui penyebab terjadinya substandard practice.

Substandar practice dapat dilihat sebagai perilaku yang ditampilkan oleh seseorang. Perilaku terbentuk oleh berbagai macam faktor demikian pula substandard practice yang terjadi karena adanya faktor yang melatarbelakanginya. Basic cause merupakan penyebab yang melatarbelakangi terjadinya substandard practice sebagai komponen dari immediate cause. Basic cause atau penyebab dasar merupakan penyebab terjadinya kecelakaan yang dapat diketahui berdasarkan faktor personal dan faktor pekerjaan. Sehingga basic cause dapat membantu menjelaskan alasan seseorang melakukan substandard practice dan menjelaskan alasan munculnya substandard condition (Bird dan Germain, 1992).

Faktor personal merupakan faktor dalam diri seseorang yang dapat menimbulkan terjadinya substandard practice. Hasil penelitian mengidentifikasi substandard practice terjadi pada pengelas dengan faktor personal yang masuk dalam kategori sedang dan buruk. Maka dapat disimpulkan bahwa faktor personal menjadi salah satu penyebab timbulnya substandard practice pada pengelas di PT. Bangun Sarana Baja sejalan dengan pernyataan dari Suma'mur (2009) bahwa salah satu penyebab kecelakaan adalah faktor manusia itu sendiri sebagai pelaksana pekerjaan. Hal ini juga diungkapkan oleh Bird dan Germain (1992) bahwa berdasarkan pengalaman, keterlibatan faktor manusia mempunyai porsi besar sebagai penyebab kecelakaan.
Hasil penelitian menunjukkan bahwa pengelas yang menggunakan safety shoes dengan kondisi tidak baik adalah pengelas yang tidak berpartisipasi dalam pelatihan. Kondisi APD yang tidak baik juga disebabkan oleh kurangnya partisipasi dalam pelatihan terutama pelatihan mengenai pemakaian, perawatan dan pemeliharaan APD yang diadakan oleh perusahaan. Partisipasi pengelas dalam pelatihan perlu mendapatkan perhatian khusus dari perusahaan. Hal ini terkait dengan tujuan pelatihan yang disebutkan oleh Mangkunegara (2003) bahwa pelatihan dapat meningkatkan produktivitas kerja, kualitas kerja, kesehatan dan keselamatan kerja. Oleh karena itu perusahaan hendaknya mampu mengimbau pekerja untuk berpartisipasi dalam pelatihan.

PT. Bangun Sarana Baja telah menjalankan program pelatihan mengenai pemakaian APD namun program tersebut hanya terfokus pada cara pemakaian APD. Dalam pelatihan hendaknya juga memberikan materi mengenai perawatan dan pemeliharaan APD yang digunakan oleh pekerja sehingga sesuai dengan undang-undang Permenakertrans No. 08/MEN/VII/2010 yang menyebutkan bahwa perusahaan wajib menjalankan program manajemen APD yang meliputi pelatihan dan perawatan APD.

Hasil penelitian menunjukkan bahwa pengelas yang menggunakan face shield dengan tidak benar adalah pengelas yang tidak berpartisipasi dalam pelatihan. Dalam pelatihan tersebut hendaknya terdapat ulasan mengenai bahaya dalam pengelasan, APD yang diperlukan dalam pengelasan beserta fungsinya, serta cara pemakaian APD yang benar dengan tujuan untuk meningkatkan pengetahuan pengelas terhadap seberapa besar bahaya pengelasan bagi kesehatan serta cara pencegahan terjadinya penyakit akibat kerja.

PT. Bangun Sarana Baja memiliki program pelatihan yang terjadwal, namun tidak memiliki standar operasional prosedur yang jelas dan tertulis mengenai program tersebut sehingga program pelatihan dapat menjadi tidak efektif. Perancangan pelatihan yang efektif menurut Donaldson dan Scannel (1987) antara lain dengan menganalisis kebutuhan pelatihan, menentukan standar, menyediakan materi, menggunakan media yang tepat, menyusun tes atau ujian setelah pelatihan.

Faktor pekerjaan merupakan setiap fasilitas yang disediakan oleh perusahaan baik alat maupun bahan serta alat pelindung diri. Berdasarkan penelitian dapat dilihat bahwa substandard practice dilakukan 
oleh pengelas yang mempunyai faktor pekerjaan dalam kategori sedang. Hal ini menunjukkan bahwa faktor pekerjaan pada pengelas di PT. Bangun Sarana Baja telah mendukung terciptanya standard practice meskipun masih terdapat beberapa pengelas yang masih melakukan substandard practice. PT. Bangun Sarana Baja telah melakukan salah satu bentuk tindakan pencegahan dengan menyediakan seluruh peralatan dengan kondisi baik dan sesuai dengan pekerjaan sebab seluruh peralatan yang digunakan dalam pekerjaan adalah sumber potensi kematian dan kecelakaan yang sangat luar biasa (Bird dan Germain, 1992).

Hasil penelitian menunjukkan bahwa pengelas yang menggunakan safety shoes dengan kondisi tidak layak adalah pengelas yang beranggapan bahwa proses penyediaan APD masih rumit dan memakan waktu lama. Kondisi APD yang demikian hendaknya ditindaklanjuti oleh perusahaan seperti yang telah ada dalam ketetapan Permenakertrans No. PER.08/MEN/VII/2010 tentang Alat Pelindung Diri pasal 8 ayat 1 disampaikan bahwa APD yang rusak, retak atau tidak dapat berfungsi dengan baik harus dibuang dan atau dimusnahkan.

Pemusnahan dan pembuangan APD yang tidak layak erat kaitannya dengan penyediaan atau pengadaan APD yang baru untuk mengganti APD yang dimusnahkan atau dibuang. Proses penyediaan APD dinilai masih rumit dan memakan waktu lama, hal ini menjadi suatu kendala baru bagi pengelas maupun PT. Bangun Sarana Baja dalam memenuhi peraturan perundangan mengenai APD. Sesuai dengan pengakuan manajemen bahwa APD yang disediakan oleh perusahaan bagi pengelas adalah face shield, apron, heat gloves, dan safety shoes namun dalam hal penggantian APD yang rusak atau tidak layak, perusahaan hanya menyediakan face shield, apron, dan heat gloves.

Penggantian safety shoes dilakukan 1 tahun sekali dan melalui proses pendataan pekerja yang tidak mempunyai safety shoes, hal tersebut dilakukan karena pihak manajemen harus melakukan pemesanan terlebih dahulu selain itu pekerja PT. Bangun Sarana Baja juga harus mengeluarkan biaya jika ingin mendapatkan safety shoes. Dalam permasalahan tersebut maka upaya yang dapat dilakukan adalah dengan melakukan perawatan dan pemeliharaan terhadap safety shoes agar tetap berfungsi dengan baik.

Hasil penelitian menunjukkan bahwa pengelas yang menggunakan face shield dengan tidak benar adalah pengelas yang bekerja tidak sesuai dengan SOP. PT. Bangun Sarana Baja mempunyai program safety induction. Program tersebut terdapat pengulasan mengenai prosedur kerja aman selain itu dalam program tersebut juga terdapat evaluasi terhadap materi yang telah diulas sepanjang safety induction yang bertujuan untuk memastikan bahwa pekerja yang baru atau pekerja pindahan telah memahami seluruh materi yang diulas dalam safety induction termasuk prosedur kerja aman. Hal tersebut merupakan salah satu upaya yang dilakukan oleh PT. Bangun Sarana Baja untuk mencegah terjadinya kecelakaan kerja, sejalan dengan pernyataan dari Bird dan Germain (1992) bahwa salah satu program yang dapat dilakukan manajemen sebagai upaya pencegahan kecelakaan kerja adalah menjelaskan setiap peraturan yang ada di perusahaan dan menjelaskan instruksi kerja yang benar pada setiap pegawai baru maupun pegawai pindahan.

Program teguran terhadap perilaku tidak aman juga dilaksanakan oleh PT. Bangun Sarana Baja namun program tersebut hanya terfokus pada pekerja yang tidak memakai salah satu APD, ada baiknya jika program teguran ini juga menyangkut tata cara penggunaan APD yang tidak sesuai dengan fungsi APD tersebut, termasuk kesalahan dalam pemakaian APD. Teguran yang diberikan termasuk salah satu fungsi atau peranan pengawas dimana pengawas atau supervisor atau mandor maupun safety officer melakukan kontak langsung secara personal. Hal ini sesuai dengan ungkapan Bird dan Germain (1992) bahwa kontak secara personal harus dilakukan sesering mungkin untuk memengaruhi sikap pekerja, pengetahuan, dan keterampilan.

Pengendalian yang dilakukan oleh manajemen adalah segala bentuk program yang dibuat dan dilakukan oleh manajemen. Secara keseluruhan, PT. Bangun Sarana Baja telah melakukan pengendalian dengan baik. Seluruh program yang dibuat dan direncanakan sudah berjalan dengan baik, namun terdapat kendala mengenai tidak adanya SOP pada setiap program yang direncanakan yang dapat mempersulit pengukuran keberhasilan program (Bird dan Germain, 1992). Dengan demikian dapat dikatakan bahwa manajemen PT. Bangun Sarana Baja hanya menjalankan beberapa fungsinya sebagai manajemen seperti yang diungkapkan oleh Bird dan Germain (1992) bahwa manajemen yang mengatur secara professional mengetahui program pengendalian kerugian atau keselamatan, 
mengetahui standard, mengetahui rencana dan mengatur pekerjaan untuk mencapai standar, memimpin semua orang untuk mencapai standar, mengukur kemampuan kerja diri sendiri dan orang lain, mengevaluasi hasil dan kebutuhan, menghargai dan membangun tindakan yang benar.

\section{SIMPULAN}

Permasalahan pokok pada program pengendalian manajemen adalah tidak tersedianya standar operasional prosedur atau SOP sehingga sulit dilakukan pengukuran terhadap keberhasilan sebuah program.

Hasil penelitian menyatakan bahwa sebanyak $20 \%$ pengelas mempunyai pengetahuan yang baik, $75 \%$ mempunyai pengetahuan sedang dan $5 \%$ mempunyai pengetahuan yang buruk. Pengetahuan sebagai faktor personal diperoleh melalui berbagai cara yakni pelatihan dan pengalaman dimana pelatihan sebagai pengembang keterampilan kerja dan pengalaman sebagai proses belajar untuk bekerja dengan baik dan tidak menimbulkan bahaya bagi diri sendiri maupun lingkungan sekitar.

Hasil penelitian menyatakan $65 \%$ pengelas yang menganggap bahwa faktor pekerjaan berada pada kategori baik. Faktor pekerjaan secara keseluruhan telah mendukung terciptanya standard practice dilihat dalam komponen peralatan dan perlengkapan serta perhatian terhadap kesalahan dan penyalahgunaan.

Komponen peralatan dan perlengkapan 55\% pengelas telah mendukung terciptanya standard practice namun penyediaan APD masih melalui proses yang rumit dan memakan waktu lama.

Komponen perhatian pada kesalahan dan penyalahgunaan $45 \%$ pengelas telah mendukung dengan adanya teguran yang diberikan oleh pengawas terhadap pengelas yang tidak memakai APD dengan baik, namun masih banyak pengelas yang bekerja tidak sesuai SOP.

Pemakaian APD pada pengelas di PT. Bangun Sarana Baja $60 \%$ pengelas telah masuk pada kategori standard practice, namun 65\% safety shoes yang digunakan memiliki kondisi yang tidak layak, selain itu $60 \%$ pengelas masih menggunakan face shield dalam keadaan tidak menutup wajah.

Penyebab terjadinya substandard practice pada pengelas di PT. Bangun Sarana Baja adalah kurangnya partisipasi pengelas dalam pelatihan dan kurangnya pengalaman pada bidang pengelasan sebelum bekerja di PT. Bangun Sarana Baja sebagai faktor personal, penyediaan APD yang rumit dan lama, kelalaian dalam memakai APD, bekerja tidak sesuai dengan SOP sebagai faktor personal, dan kurangnya pengendalian dari perusahaan dalam pembuatan standar untuk setiap program.

Penyebab terjadinya substandard practice pada pengelas di PT. Bangun Sarana Baja adalah kurangnya partisipasi pengelas dalam pelatihan dan kurangnya pengalaman pada bidang pengelasan sebelum bekerja di PT. Bangun Sarana Baja sebagai faktor personal, penyediaan APD yang rumit dan lama, kelalaian dalam memakai APD, bekerja tidak sesuai dengan SOP sebagai faktor personal, dan kurangnya pengendalian dari perusahaan dalam pembuatan standar untuk setiap program.

\section{DAFTAR PUSTAKA}

Bird and Germain. 1992. Practical Loss Control Leadership, United States of America: International Loss Control Institute.

Ditjen RI. 2011. Himpunan Peraturan Perundangundangan Keselamatan dan Kesehatan Kerja. Jakarta: Kementerian Tenaga Kerja dan Transmigrasi R.I, 811-812.

Donaldson, Les dan Scannel, Edward E. 1987. Pengembangan Sumber Daya Manusia: Panduan bagi Pelatih Muda. Edisi terjemahan oleh Suyuti, Ya'kub, Moh dan Syafruddin, Eko. Jakarta: Gaya Media Pratama.

Foster, B. 2001. Pembinaan untuk Peningkatan Karyawan. Jakarta: PPM.

Geller, E.S. 2001. The Psychology of Safety Handbook, United State of America: CRC Press LLC Lewis Publishers is an imprint of CRC Press LLC.

Geller, E.S. 2005. Behavior-Based Safety and Occupational Risk Management, Virginia Polytechnic Institute and State University: Sage Publication.

John, E.B. 2007. Contextual Teaching and Learning. Terjemahan Ibnu Setiawan. Bandung: MLC.

Mangkunegara, A.A. Anwar Prabu. 2003. Perencanaan dan Pengembangan Sumber Daya Manusia. Bandung: PT. Refika Aditama.

Mustaqim. 2004. Psikologi Pendidikan. Yogyakarta: Pustaka Pelajar.

Notoadmodjo, Soekidjo. 2003. Pendidikan dan Perilaku Kesehatan. Jakarta: Rineka Cipta.

Notoadmodjo, S. 2007. Kesehatan Masyarakat Ilmu dan Seni. Jakarta: PT Rineka Cipta. 
Reason, J. 2008. The Human Contribution: Unsafe Act, Accident and Heroic Recoveries. USA: Ashgate.

Riswan, D.J. 2008. Diktat Teori Fabrikasi 2. Yogyakarta: Universitas Negeri Yogyakarta.

Safrin, Afrizal. 2007. Evaluasi dan Perbaikan Rancangan Topeng Las Berbasis Studi Ergonomi dan K3. Tugas Akhir. Surabaya: Jurusan Teknik Industri ITS.

Santoso dan Tjiptono. 2004. Riset Pemasaran Konsep dan Aplikasi dengan SPSS. Jakarta: PT Elex Media Komputindo.
Shappell dan Wiegman. 2000. The Human Factors Analysis and Classification System-HFACS. Oklahoma: Institute of Aviation.

Siswanto, A. 1994. Toksikologi Industri. Surabaya: Balai Hiperkes dan Keselamatan Kerja Jawa Timur Departemen Tenaga Kerja.

Siswanto, A. 2009. Bahaya Bahan Kimia. Surabaya: Balai Hiperkes dan Keselamatan Kerja.

Suma'mur. 1996. Higiene Perusahaan dan Kesehatan Kerja. Jakarta: Gunung Agung.

Suma'mur. 2009. Higiene Perusahaan dan Kesehatan Kerja (HIPERKES). Jakarta: Sagung Seto. 